\title{
Alveolar epithelial lining fluid cellularity, protein and endothelin-1 in children with congenital heart disease
}

\author{
J. Grigg, S. Kleinert, R.L. Woods, C.J. Thomas, P. Vervaart, \\ J.L. Wilkinson, C.F. Robertson
}

Alveolar epithelial lining fluid cellularity, protein and endothelin-1 in children with congenital heart disease. J. Grigg, S. Kleinert, R.L. Woods, C.J. Thomas, P. Vervaart, J.L. Wilkinson, C.F. Robertson. @ERS Journals Ltd 1996.

ABSTRACT: This study applied bronchoalveolar lavage (BAL) to children with congenital heart disease (CHD) prior to elective cardiac catheterization $(n=48)$, to determine the influence of pulmonary blood flow and viral infection on the alveolar epithelial lining fluid (ELF) concentration of leucocytes, protein and endothelin-1 (ET-1).

Lower respiratory tract (LRT) viral infection was defined as either a positive immunofluorescence for virus, or a virus cultured from the bronchoalveolar lavage fluid (BALF). Haemodynamic status was determined at cardiac catheterization. Normative data for BALF, but not ELF parameters, were obtained from 26 asymptomatic, noninfected normal children undergoing elective surgery.

In the absence of LRT infection, the BALF macrophage, lymphocyte and neutrophil differential in CHD was not significantly different from the normal controls. In CHD, both increased pulmonary-to-systemic flow ratio $\left(Q^{\prime} p / Q^{\prime}\right.$ s) and increased pulmonary artery-to-left ventricular pressure ratio $\mathbf{P A P} / \mathrm{LVP}$ were associated with a decrease in $\mathrm{ELF}$ protein $\left(\mathrm{r}_{\mathrm{s}}=\mathbf{- 0 . 5 9} ; \mathrm{p}<0.0001\right.$; and $\mathrm{r}_{\mathrm{s}}=\mathbf{- 0 . 5 0} ; \mathrm{p}<0.0001$ respectively). A respiratory virus was isolated from the BALF in $8(17 \%)$ of CHD children. Virus isolation was associated with an increased ELF total protein $(\mathrm{p}<0.05$ vs no infection), a decreased alveolar macrophage differential count $(p<0.01)$, and an increased neutrophil differential count $(\mathbf{p}<0.05)$. ET-1 was detected in the BALF of $83 \%$ of the noninfected CHD children compared to only $23 \%$ of the controls $(p<0.001)$. ELF ET-1 concentrations did not correlate with haemodynamic status in CHD, but were up to 100 times higher than paired plasma levels.

We conclude that, in congenital heart disease, both lower respiratory tract viral infection and increased pulmonary blood flow and/or pulmonary vascular pressure influence the alveolar milieu. High alveolar epithelial lining fluid concentrations of endothelin-1 occur in congenital heart disease, but the stimulus for pulmonary endothelin-1 production is unclear.

Eur Respir J., 1996, 9, 1381-1388.
Depts of Thoracic Medicine, Cardiology and Biochemistry, Royal Children's Hospital and The Baker Medical Research Institute, Melbourne, Victoria, Australia.

Correspondence: J. Grigg

Dept of Paediatrics

St Mary's NHS Trust

Praed Street

London W2 $1 \mathrm{NY}$

UK

Keywords: Bronchoalveolar lavage congenital heart disease endothelin-1

Received: July 131995

Accepted after revision March 251996

J.G. is a recipient of a Scadding-Morriston Davies Scholarship.
The effect of congenital intracardiac shunts on the profile of alveolar cells and solutes is unknown. However, there is indirect evidence that changes in the alveolar milieu are present in paediatric congenital heart disease (CHD). For example, decreased pulmonary compliance, tachypnoea, wheezing and cough are associated with an increased pulmonary-to-systemic flow ratio $\left(Q^{\prime} \mathrm{p} / Q^{\prime} \mathrm{s}\right)[1$, $2]$. Consequently, it is difficult to determine the aetiology of lower respiratory (LRT) symptoms in children with large left-to-right intracardiac shunts, since similar symptoms may also be caused by intercurrent viral infection. Bronchoalveolar lavage (BAL) samples the alveolar milieu [3, 4], and is a potential method of describing cardiopulmonary interactions in vivo. Although BAL by elective fibreoptic bronchoscopy for research is ethically unacceptable in children, nonbronchoscopic BAL (NB-BAL) is feasible when access to the lower airway is provided for clinical indications. In our institution, elective cardiac catheterization is performed under general anaesthesia. Using NB-BAL, we therefore sought to identify some of the factors influencing the alveolar milieu in a cohort of children with CHD. We further aimed to assess whether the pattern of alveolar epithelial lining fluid (ELF) leucocytes, protein and endothelin-1 (ET-1) could help to distinguish haemodynamic-induced from viral-induced LRT symptoms.

ET-1 was chosen, firstly, because an association between increased pulmonary blood flow and elevated plasma ET-1 has been reported in CHD [5, 6] and secondly, because ET-1 is a potent bronchoconstrictor [7]. If high airway concentrations of ET-1 are present in CHD, bronchospasm could be induced through endothelin-A (ETA) receptors on the pulmonary bronchial smooth muscle [7]. ELF total protein and alveolar leucocytes were measured since both are affected by viral infection [8-10]. To obtain normative data, BAL was performed on a group 
of normal children undergoing routine surgery. Since plasma for urea was not obtained from the normal controls, only BAL fluid (BALF) leucocyte concentrations were determined.

\section{Methods}

\section{Subjects}

All children with CHD undergoing elective cardiac catheterization were eligible for BAL. Forty eight children with CHD were studied from August 1993 until July 1994. The study was approved by the Ethics in Human Research Committee of the Royal Children's Hospital and required full informed, written parental consent. The day before cardiac catheterization and without prior knowledge of the pulmonary haemodynamic status, a respiratory symptom history was obtained and the child was examined for abnormal respiratory signs. Children with rhinitis were diagnosed as having upper respiratory tract symptoms. LRT symptoms/signs were classified as the presence of cough, tachypnoea, retractions, wheeze or crackles. If the awake respiratory rate was $>50$ breaths $\cdot \mathrm{min}^{-1}$, the sleeping respiratory rate was measured. Tachypnoea was defined as a sleeping respiratory rate $>50$ breaths $\cdot \mathrm{min}^{-1}$, i.e. greater than the 95th percentile for this age range [11]. Normal controls were obtained from children undergoing elective posterior medial release for club feet $(n=24)$ and ureteric reimplantation $(n=2)$. Children with chronic respiratory conditions, LRT symptoms or LRT infection were excluded as controls. Haemodynamic measurements were not performed on the normal controls.

\section{Bronchoalveolar lavage}

Immediately prior to cardiac catheterization, or elective surgery, BAL was performed by a single operator (JG) using a modification of the technique described by KombOURLis and KuRLand [12]. Apart from the mode of delivery, NB-BAL was identical to our standardized fibreoptic BAL protocol [13]. Children were anaesthetized with isofluorane, intravenous thiopentone and pancuronium. Immediately after intubation and with the child's head turned to the left, a 6,7 or 8 French straight $60 \mathrm{~cm}$ end hole suction catheter (Vygon S.A., Écouen, France) was inserted into the endotracheal (ET) tube through a right-angle swivel bronchoscope connector (Mallinckrodt Medical Pty. Ltd, Australia). The suction catheter size was determined by the diameter of the ET tube. The catheter was advanced until wedged, $1 \mathrm{~mL} \cdot \mathrm{kg}^{-1}$ body weight (BW) saline instilled and BALF immediately aspirated into a suction trap via a three-way tap using 150 $\mathrm{mmHg}$ negative pressure. Without removing the catheter, two further aliquots of $1 \mathrm{~mL} \cdot \mathrm{kg}^{-1} \mathrm{BW}$ saline were then instilled and aspirated. Pooled BALF was placed on ice for processing. A sample of BALF underwent bacteriological and virological analysis. In total, the lavage procedure lasted less than $30 \mathrm{~s}$. The BALF total cell concentration was determined by haemocytometer and a cell preparation obtained by Cytospin at $900 \mathrm{rpm}$ for $5 \mathrm{~min}$
(Cytospin 2; Shandon Products Ltd, UK). BALF cells were stained with Wilson's stain reagents. Under oil microscopy $(\times 1,000$ magnification), specific leucocyte differential counts $(\%)$ were calculated from $>300$ leucocytes. BALF leukocyte concentrations were calculated after correcting for epithelial cells. Cell-free supernatant was obtained by centrifugation of BALF at $1,000 \times \mathrm{g}$ for $10 \mathrm{~min}\left(4^{\circ} \mathrm{C}\right)$ and $8,000 \times \mathrm{g}$ for a further $3 \mathrm{~min}\left(4^{\circ} \mathrm{C}\right)$. Cell-free BALF was stored at $-70^{\circ} \mathrm{C}$. Blood was not obtained from normal control children for ethical reasons.

\section{Cardiac catheterization}

Catheterization was performed under general anaesthesia and the fractional concentration of inspired oxygen maintained at 0.3 . Pressure measurements were obtained using fluid-filled catheters connected to pressure transducers. The $Q$ ' $\mathrm{p} / Q^{\prime}$ 's was calculated from the Fick principle [14]. Two haemodynamic variables were recorded for this study, $Q^{\prime} \mathrm{p} / Q^{\prime}$ 's and the ratio of systolic pulmonary artery-to-systolic left ventricular pressure (PAP/LVP). Other haemodynamic measurements were recorded as indicated for the cardiac investigation, but were not analysed in this study. During catheterization, blood was sampled from the left ventricle and was analysed for total protein and urea using routine hospital biochemical techniques. Left ventricular blood was also collected into a chilled ethylenediamine tetra-acetic acid (EDTA) coated tube, transported immediately on ice and centrifuged at 1,000 $\times \mathrm{g}$ for $15 \mathrm{~min}$ at $4^{\circ} \mathrm{C}$. Plasma was stored at $-70^{\circ} \mathrm{C}$ for ET- 1 analysis.

\section{BALF microbiology and virology}

Samples of BALF were analysed for viruses using immunofluorescence and cytopathic effect during culture with human fibroblasts, monkey kidney and Helen-Lake (HeLa) cell lines. All common respiratory viruses, including coronavirus, could be identified with this combination. If nasal secretions were present, a nasopharyngeal aspirate (NPA) was performed. Primary, secondary and tertiary aerobic and anaerobic bacteriological cultures were performed using $10 \mu \mathrm{L}$ of BALF. All potential bacterial pathogens were identified and reported using a semiquantitative analysis that had previously been validated using quantitative BALF cultures from children with cystic fibrosis $\left(<10^{4}\right.$ colony forming units $(\mathrm{cfu}) \cdot \mathrm{mL}^{-1}, 10^{4}-10^{6}$ $\mathrm{cfu} \cdot \mathrm{mL}^{-1}$, and $>10^{6} \mathrm{cfu} \cdot \mathrm{mL}^{-1}$ ) (D. Armstrong, personal communication). Bacterial cultures could not detect Chlamydiae or Mycoplasma pneumoniae. LRT infection was defined as either the detection of a virus from the BALF and/or the isolation of a bacterial pathogen at concentrations of $\geq 10^{4} \mathrm{cfu} \cdot \mathrm{mL}^{-1}[15]$.

\section{BALF total protein, albumin and urea}

All assays were performed using a Roche Cobas Bio centrifugal analyser (Roche Diagnostics, Basel, Switzerland). Total protein in $50 \mu \mathrm{L}$ BALF was determined using benzethonium chloride [16]. The linear dynamic range for 
the assay was from $0.03-0.4 \mathrm{~g} \cdot \mathrm{L}^{-1}$. BALF urea was measured using a modification of a commercially available kit (Sigma UV-66; Sigma Chemical Co., St. Louis, MO, USA). The kit was modified by increasing the sample volume to $50 \mu \mathrm{L}$, decreasing the reagent volume to 250 $\mu \mathrm{L}$ and increasing the assay duration to $6 \mathrm{~min}$. The linear dynamic range for urea was $18-500 \mu \mathrm{mol} \cdot \mathrm{L}^{-1}$. The interassay coefficient of variation $(\mathrm{CoV})$ for all assays was $<9 \%$.

\section{Endothelin-1 assay}

ET-1 was measured in BALF and plasma by radioimmunoassay (RIA). All plasma samples were measured after extraction of the peptide. The ET-1 RIA used a commercial antiserum (Peninsula Laboratories, Belmont, Ca, USA) at the recommended dilution in a volume of 100 $\mu \mathrm{L}$. Cross-reactivity to human ET-1 was $100 \%$, $7 \%$ for endothelin-2 and -3 (ET-2 and ET-3) and 17\% for big ET-1. Tracer (125I-ET-1) was purchased from Amersham International plc. (Bucks, UK) and used at a concentration of approximately 10,000 counts per minute (cpm) 100 $\mu L^{-1}$. Synthetic ET-1 (Peninsula Laboratories) was used as the standard in a range of $0.5-500 \mathrm{pg} \cdot 100 \mu \mathrm{L}^{-1}$ tube. The assay buffer was sodium phosphate $(0.1 \mathrm{M}), \mathrm{pH} 7.4$, with $0.1 \%$ Triton-X 100 and $0.1 \%$ bovine serum albumin. After a $24 \mathrm{~h}$ incubation at $4^{\circ} \mathrm{C}$, separation of antibody-bound ET-1 from free ET-1 was achieved with 100 $\mathrm{uL}$ of Sac-Cel solid phase second antibody coated cellulose suspension (anti-rabbit; I.D.S., Washington). Supernatants were aspirated and the bound fractions in the pellet counted. The limit of detection of the assay was $0.5 \mathrm{pg} \cdot$ tube $^{-1}$.

Plasma ET-1. Plasma samples were centrifuged at $4^{\circ} \mathrm{C}$ after thawing. Trifluoroacetic acid (TFA; $0.5 \mathrm{~mL}, 0.1 \%$ ) was added to each $0.5 \mathrm{~mL}$ aliquot of plasma. After blending in a vortex mixer, plasma samples were recentrifuged $\left(4^{\circ} \mathrm{C}\right)$ and loaded onto Sep-Pak $\mathrm{C}_{18}$ cartridges (Waters, Millipore, MA, USA) containing $0.5 \mathrm{~mL}$ assay buffer. Final elution was with $3 \mathrm{~mL} 80 \%$ methanol and $0.1 \%$ TFA. Extracts were dried overnight, reconstituted in 500 $\mu \mathrm{L}$ assay buffer, and $200 \mu \mathrm{L}$ aliquots were assayed in duplicate. Recovery of added ET-1 to plasma was $73 \%$ (range $66-79 \%$ for $25-100$ pg added ET-1). The limit of detection for samples was $1.6 \mathrm{pg} \cdot \mathrm{mL}^{-1}$ of plasma extract. Plasma ET-1 from normal controls was not measured.

BALF ET-1. Because of limited BALF sample volume, ET-1 was measured directly on $200 \mu \mathrm{L}$ of BALF. For each BALF-RIA, a standard curve was constructed from assay tubes containing the usual quantities of antibody tracer and standard (as described above), but with the addition of $200 \mu \mathrm{L}$ BALF from a normal subject with a negligible level of ET-1. The final volumes of standard and sample tubes were equalized to $500 \mu \mathrm{L}$. The limit of detection of direct measurements of standard ET-1 added to BALF was $2.5 \mathrm{pg} \cdot \mathrm{mL}^{-1}$. Interassay $\mathrm{CoV}$ on BALF samples was $15 \%$ at $3.9 \mathrm{pg}$ and $7.4 \%$ at $15 \mathrm{pg}$. The addition of BALF to the assay standard curve avoided problems associated with interference from nonspecific substances in unextracted BALF. There was sufficient volume in five samples to compare direct measurements with measurements on extracted samples (as described above for plasma samples). The mean difference ( \pm SEM) in concentration between ET-1 extracted from BALF vs ET-1 directly measured in BALF was $3 \pm 9 \%$.

\section{Calculation of ELF volume}

ELF volume was calculated using the urea dilution technique [17]. The ELF concentration was not calculated when the BALF concentration of solute was below the assay detection limit. Blood urea was not available for the normal controls and ELF concentrations of cells and solutes were not estimated.

\section{Statistical analysis}

Data was analysed using Statistical Package for the Social Sciences (SPSS)® for Windows ${ }^{\mathbb{T M}}$ (SPSS Inc., Chicago, IL, USA). Results are expressed as median and interquartile range, unless indicated [18]. Univariate comparisons between groups were performed by using the MannWhitney U-test. Correlations were obtained using Spearman's rank correlation (coefficient $=\mathrm{r}_{\mathrm{s}}$ ). Proportions were compared using the Chi-squared test. Stepwise multivariate linear regression analysis was performed after normalization of residuals by $\log _{10}$ transformation. Statistical significance was accepted for p-values less than 0.05 .

\section{Results}

The clinical diagnoses of children with CHD are described in table 1. $Q$ 'p $/ Q$ 's ratios were calculated for all CHD children $(n=48)$ and PAP/LVP ratios calculated in all but one child. Twenty two CHD children (46\%) had increased pulmonary blood flow as defined by a $Q$ 'p $/ Q$ 's $\geq 1.5$, and eight $(17 \%)$ had increased pulmonary vascular pressure (PAP/LVP $\geq 0.5$ ). Elevations in vascular pressure were all related to increased pulmonary blood flow, and the correlation between $Q^{\prime} \mathrm{p} / Q^{\prime}$ 's and PAP/LVP was,

Table 1. - Clinical details of children with congenital heart disease

\begin{tabular}{lccc}
\hline $\begin{array}{l}\text { Primary } \\
\text { pathology }\end{array}$ & $\begin{array}{c}\text { No } \\
\text { surgery } \\
\mathrm{n}\end{array}$ & $\begin{array}{c}\text { Post-palliative } \\
\text { surgery* } \\
\mathrm{n}\end{array}$ & $\begin{array}{c}\text { Post-definitive } \\
\text { surgery* } \\
\mathrm{n}\end{array}$ \\
\hline VSD & 13 & 0 & 0 \\
Fallot's tetralogy & 3 & 3 & 1 \\
AVSD & 4 & 0 & 1 \\
ASD & 4 & 0 & 0 \\
TGA & 4 & 0 & 0 \\
CoA & 0 & 0 & 4 \\
PDA & 3 & 0 & 0 \\
PVS & 1 & 0 & 0 \\
PA+VSD & 0 & 1 & 0 \\
Other & 3 & 3 & 0
\end{tabular}

*: at least 6 weeks postsurgery. VSD: ventricular septal defect; AVSD: atrio-ventricular septal defect; ASD: atrial septal defect; TGA: transposition of the great arteries; CoA: coarctation of the aorta; PDA: patent ductus arteriosus; PVS: pulmonary valve stenosis; PA: pulmonary atresia. 
therefore, significant $\left(r_{\mathrm{s}}=0.65 ; \mathrm{p}<0.0001\right)$. BAL was welltolerated, with no clinically significant decrease in oxygen saturation during or after the procedure.

\section{LRT infection and CHD}

Forty CHD children had no LRT infection (noninfected group). A virus was isolated from the BALF of eight children (infected group). In five children, LRT viral infection was associated with Moraxella catarrhalis and/ or Haemophilus influenzae at levels $\geq 10^{4} \mathrm{cfu} \cdot \mathrm{mL}^{-1}$ (table 2 ). No child had a LRT bacterial infection alone. LRT viral infection was associated with a lower percentage of alveolar macrophages, a higher percentage of neutrophils and increased concentrations of neutrophils, lymphocytes and eosinophils (fig. 1 and table 3 ).

LRT infection was associated with increased ELF concentrations of total protein (fig. 2 and table 3). Plasma

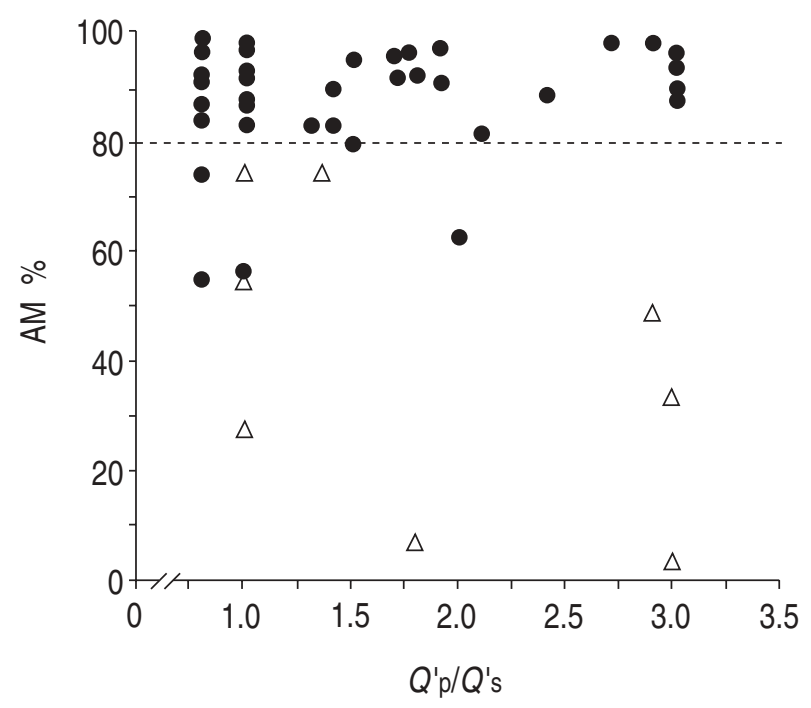

Fig. 1. - Scatterplot of the alveolar macrophage (AM) differential against the pulmonary-to-systemic blood flow ratio $\left(Q^{\prime} \mathrm{p} / Q^{\prime} \mathrm{s}\right)$. The horizontal line (-.-.) indicates the $80 \%$ cut-off point for excluding infection. $\Delta$ : lower respiratory tract infection; $\bullet$ : noninfected children. protein was measured in five children with LRT infection and the ELF plasma total protein ratio was increased in this subgroup (table 3). Multivariate analysis confirmed an independent association between LRT viral infection and both increased ELF total protein and increased ELF total cell concentrations (table 4).

Table 3. - Univariate comparison between infected and noninfected children with CHD

\begin{tabular}{|c|c|c|c|}
\hline & $\begin{array}{l}\text { Noninfected LRT } \\
\qquad(\mathrm{n}=40)\end{array}$ & $\begin{array}{l}\text { Infected LRT } \\
(\mathrm{n}=8)\end{array}$ & p-value \\
\hline \multicolumn{4}{|c|}{ Respiratory symptoms\# } \\
\hline asymptomatic & $29(73)$ & $2(25)$ & \\
\hline URT only & $3(8)$ & $1(13)$ & \\
\hline LRT only & $2(5)$ & $4(50)$ & \\
\hline URT + LRT & $6(15)$ & $1(13)$ & \\
\hline Age months* & $12(5-17)$ & $6.0(2.8-24)$ & NS \\
\hline$Q^{\prime} \mathrm{p} / Q^{\prime} \mathrm{s} *$ & $1.35(0.85-1.97)$ & $1.58(1-2.97)$ & NS \\
\hline PAP/LVP* & $0.3(0.30-0.34)$ & $0.35(0.3-0.4)$ & NS \\
\hline \multicolumn{4}{|c|}{ Epithelial lining fluid* } \\
\hline AM \% & $91.6(84-96)$ & $41.3(11-69)$ & $<0.001$ \\
\hline PMN \% & $1.8(0.6-2.9)$ & $28.5(16-84)$ & $<0.001$ \\
\hline LYM \% & $4(2.3-8.6)$ & $9.6(1.6-320$ & NS \\
\hline EOS \% & $0(0-0)$ & $0.12(0-0.3)$ & NS \\
\hline $\mathrm{AM} \times 10^{5} \cdot \mathrm{mL}^{-1}$ & $55.8(37-112)$ & $73.6(29-136)$ & NS \\
\hline $\mathrm{PMN} \times 10^{5} \cdot \mathrm{mL}^{-1}$ & $0.84(0.5-2.1)$ & $56.3(12-319)$ & $<0.001$ \\
\hline $\mathrm{LYM} \times 10^{5} \cdot \mathrm{mL}^{-1}$ & $2.9(0.6-6.7)$ & $15.2(0.5-58)$ & $<0.02$ \\
\hline EOS $\times 10^{5} \cdot \mathrm{mL}^{-1}$ & $0(0-0)$ & $0.13(0-1.1)$ & $<0.02$ \\
\hline $\begin{array}{l}\text { Total protein } \\
\mathrm{mg} \cdot \mathrm{mL}^{-1}\end{array}$ & $3.9(2.3-5.3)$ & $8.0(4.1-12.9)$ & ) $<0.01$ \\
\hline $\mathrm{ET}-1 \mathrm{pg} \cdot \mathrm{mL}^{-1}$ & $\begin{array}{c}298 \begin{array}{c}(163-424) \\
(\mathrm{n}=30)\end{array}\end{array}$ & $\begin{array}{c}179 \begin{array}{c}(114-211) \\
(\mathrm{n}=7)\end{array} \\
\end{array}$ & l) $<0.05$ \\
\hline $\begin{array}{c}\text { ELF/plasma total } \\
\text { protein* }\end{array}$ & $\begin{array}{c}0.06 \begin{array}{c}(0.03-0.08) \\
(\mathrm{n}=24)\end{array}\end{array}$ & $\begin{array}{c}0.12 \begin{array}{c}(0.06-0.17 \\
(\mathrm{n}=5)\end{array}\end{array}$ & 17) $<0.05$ \\
\hline $\begin{array}{l}\text { Plasma ET-1* } \\
\text { pg.mL-1 }\end{array}$ & $\begin{array}{c}6.9 \begin{array}{c}(5.6-8.9) \\
(\mathrm{n}=28)\end{array}\end{array}$ & $\begin{array}{c}9.1\left(\begin{array}{c}(7-11.3) \\
(\mathrm{n}=4)\end{array}\right.\end{array}$ & NS \\
\hline
\end{tabular}

\#: absolute number,and percentage in parenthesis; *: median, and interquartile range in parenthesis; CHD: congenital heart disease; LRT: lower respiratory tract; URT: upper respiratory tract; $Q$ 'p $/ Q$ 's: ratio of pulmonary-to-systemic blood flow; PAP/LVP: ratio of systolic pulmonary arterial pressure-to-left ventricular pressure; AM: alveolar macrophage; PMN: neutrophil; LYM: lymphocyte; EOS: eosinophil; ELF: epithelial lining fluid; ET-1: endothelin-1; NS: nonsignificant.

Table 2. - Clinical details of congenital heart disease children with an intercurrent lower respiratory tract infection

\begin{tabular}{|c|c|c|c|c|c|c|c|}
\hline $\begin{array}{l}\mathrm{Pt} \\
\text { No. }\end{array}$ & Diagnosis & $Q^{\prime} \mathrm{p} / Q^{\prime} \mathrm{s}$ & $\begin{array}{l}\text { Respiratory } \\
\text { symptoms }\end{array}$ & $\begin{array}{l}\text { NPA } \\
\text { virus }\end{array}$ & $\begin{array}{l}\text { BALF } \\
\text { virus }\end{array}$ & $\begin{array}{l}\text { BALF } \\
\text { bacteria }\end{array}$ & $\begin{array}{l}\text { Bacteria in } \\
\text { neutrophils }\end{array}$ \\
\hline 1 & PVS & 1.0 & Nil & CMV & CMV & No growth & No \\
\hline 2 & TA, PAPVD & 2.9 & Retr., Tachy & CMV & CMV & M. cat. $\left(>10^{4}\right)$ & Yes \\
\hline 3 & $\mathrm{CoA}$ & 1.0 & Nil & Not done* & Rhinovirus & H. infl. $\left(>10^{4}\right)$ & No \\
\hline 4 & VSD & 3.0 & $\begin{array}{l}\text { Retr., Tachy., } \\
\text { Cough }\end{array}$ & CMV & Parainfluenza & $\begin{array}{l}\text { M. cat. }\left(10^{6}\right) \\
\text { H. infl. }\left(>10^{4}\right)\end{array}$ & Yes \\
\hline 5 & VSD & 1.4 & Rhinitis & Rhinovirus & CMV & No growth & No \\
\hline 6 & VSD & 3.0 & $\begin{array}{l}\text { Rhinitis, Retr., } \\
\text { Tachy., Cough }\end{array}$ & Not done & Rhinovirus & M. cat. $\left(10^{6}\right)$ & Yes \\
\hline 7 & ASD & 1.8 & Cough & Not done* & $\begin{array}{l}\text { Rhinovirus } \\
\text { Parainfluenza }\end{array}$ & $\begin{array}{l}\text { M. cat. }\left(10^{6}\right) \\
\text { H. infl. }\left(\geq 10^{4}\right)\end{array}$ & Yes \\
\hline 8 & Fallot's & 1.0 & Cough & Not done* & RSV & No growth & No \\
\hline
\end{tabular}

Pt: patient; $Q^{\prime} \mathrm{p} / Q^{\prime}$ s: ratio of pulmonary-to-systemic blood flow; NPA: nasopharyngeal aspirate; BALF: bronchoalveolar lavage fluid; TA: tricuspid atresia; PAPVD: partial anomalous pulmonary venous drainage; Retr.: retractions; Tachy.: tachypnoea; CMV: cytomegalovirus; RSV: respiratory syncytial virus; M. cat.: Moraxella catarrhalis; H. infl.: Haemophillus influenzae; $>10^{4}$ and $\geq 10^{6}$ : colony forming units $\cdot \mathrm{mL}^{-1}$. *: no secretions in nasopharynx. For further definitions see legend to table 1. 


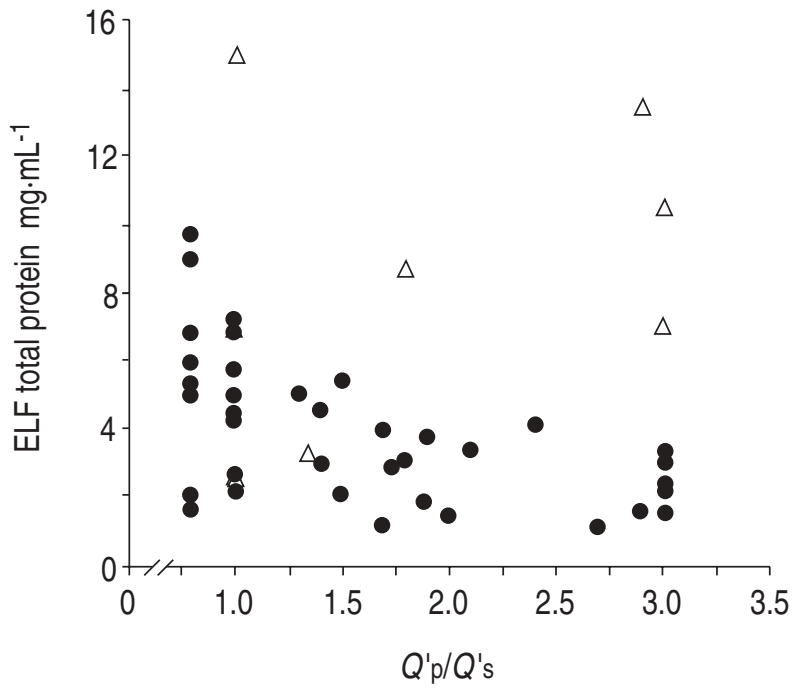

Fig. 2. - Scatterplot of the alveolar epithelial lining fluid (ELF) total protein concentration against the ratio of the pulmonary-to-systemic blood flow $\left(Q^{\prime} \mathrm{p} / Q^{\prime} \mathrm{s}\right) . \quad \Delta$ : lower respiratory tract infection; $\bullet$ : noninfected children.

\section{Pulmonary haemodynamics and CHD}

In the noninfected group, there was no correlation between pulmonary haemodynamic changes $(Q ' \mathrm{p} / Q$ 's, $\mathrm{PAP} / \mathrm{LVP}$ ) and the percentage of macrophages and neutrophils (fig. 1). However, there was a trend for the ELF total cell concentration to decrease with increased $Q$ 'p/ $Q$ 's $\left(\mathrm{r}_{\mathrm{s}}=-0.57 ; \mathrm{p}=0.06\right)$. The ELF total protein concentration decreased with increased PAP/LVP $\left(\mathrm{r}_{\mathrm{s}}=-0.50\right.$; $\mathrm{p}<0.0001)$ and increased $Q^{\prime} \mathrm{p} / Q^{\prime} \mathrm{s}\left(\mathrm{r}_{\mathrm{s}}=-0.59 ; \mathrm{p}<0.0001\right)$ (fig. 2). The ELF/plasma total protein ratio also decreased with increased $Q^{\prime} \mathrm{p} / Q^{\prime} \mathrm{s}\left(\mathrm{r}_{\mathrm{s}}=-0.46 ; \mathrm{p}<0.05\right)$ and PAP/LVP $\left(r_{s}=-0.41 ; p<0.05\right)$, in the subgroup where plasma total protein was measured $(\mathrm{n}=24)$. PAP/LVP and $Q^{\prime} \mathrm{p} / Q^{\prime}$ 's were collinearly associated and both variables were independently associated with decreased ELF total protein when entered separately into the regression model (table 4).

\section{Endothelin-1 and CHD}

Thirty two plasma samples from CHD children were available for ET-1 analysis. There was a trend for plasma ET-1 concentration to decrease with age $\left(r_{s}=0.32\right.$; $\mathrm{p}=0.09$ ), but there was no significant correlation between plasma ET-1 and haemodynamic status. There was a trend for plasma ET-1 to be higher with LRT infection $(\mathrm{p}=0.09)$ (table 3).

In CHD, the concentration of ET-1 in ELF could be estimated in 37 BALF samples. ELF ET-1 was always

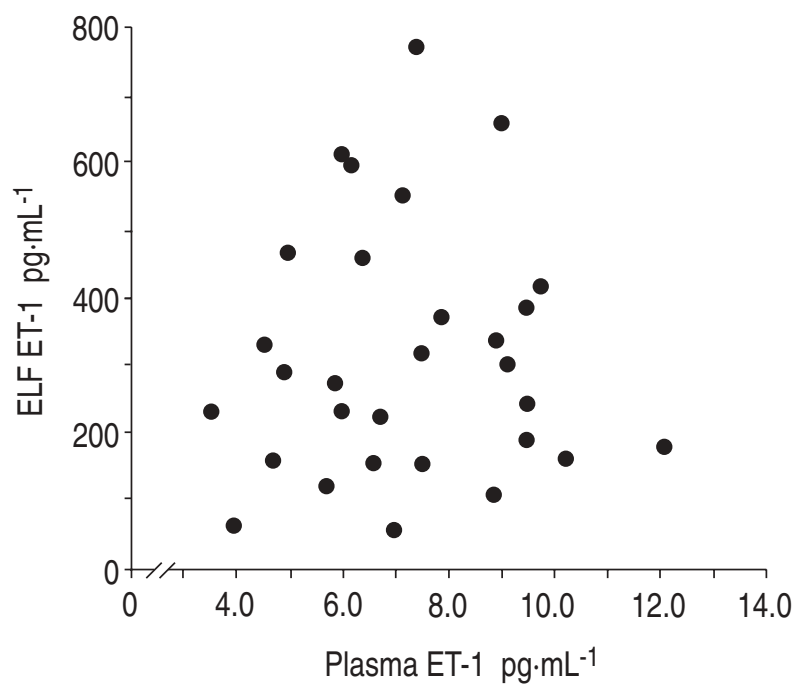

Fig. 3. - Scatterplot of the relationship between plasma and epithelial lining fluid (ELF) endothelin-1 (ET-1). There is no significant correlation between the two variables.

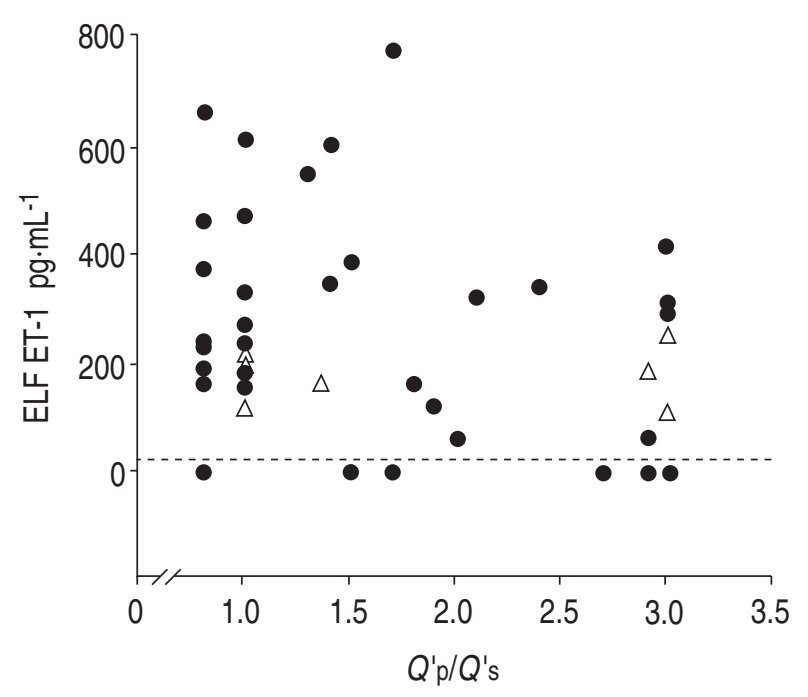

Fig. 4. - Scatterplot of the epithelial lining fluid (ELF) endothelin-1 (ET-1) against the ratio of pulmonary-to-systemic blood flow $\left(Q^{\prime} \mathrm{p} / Q^{\prime} \mathrm{s}\right)$. Points below the horizontal line ( $\ldots-\ldots)$ represent ET-1 concentrations below the assay detection limit. $\Delta$ : lower respiratory tract infection; •: noninfected children.

above the paired plasma concentration (median ELF vs plasma: 280 vs $7.1 \mathrm{pg} \cdot \mathrm{mL}^{-1}$ ), with no correlation between the plasma and ELF concentrations (fig. 3). There was no significant correlation between ELF ET-1 and either $Q$ 'p/Q's (fig. 4) or PAP/LVP. The ELF ET-1 concentration was significantly lower in LRT viral infection (fig. 4 and table 3 ).

Table 4. - Final stepwise multivariate models with epithelial lining fluid measurements as the dependent variables in children with CHD

\begin{tabular}{lccccc}
\hline & \multicolumn{5}{c}{ Independent variables, $\beta(\mathrm{sE} \beta)$} \\
\cline { 2 - 5 } Dependent variable & $\mathrm{n}$ & $\mathrm{R}^{2}$ & LRT infection & $Q^{\prime} \mathrm{p} / Q^{\prime} \mathrm{s}(\log 1)^{\#}$ & Other variables ${ }^{\dagger}$ \\
\hline ELF total protein $\left(\log _{10}\right)$ & 48 & 0.31 & $0.341(0.08)^{* * *}$ & $-0.433(0.15)^{* *}$ & $\mathrm{NS}$ \\
ELF total cell concentration & 48 & 0.24 & $0.500(0.13)^{* * *}$ & $\mathrm{NS}$ & NS \\
\hline
\end{tabular}

$\beta$ : standardized regression coefficient; sE $\beta$ : standard error of $\beta$; \#: ratio of systolic pulmonary artery pressure to systolic left ventricular also significant if entered instead of $Q^{\prime} \mathrm{p} / Q^{\prime} \mathrm{s} ;{ }^{\dagger}$ : variables entered but never reached significance were: age, sex, weight, $\%$ bronchoalveolar fluid return, previous operation, and previous wheeze. $* *: p<0.01 ; * * *: p<0.001$. For further definitions see legend to table 3 . 


\section{Respiratory symptoms and CHD}

LRT symptoms were present in CHD children with and without LRT viral infection (table 3). Noninfected children with LRT symptoms had higher $Q$ 'p/Q's and PAP/LVP ratios compared to noninfected children without LRT symptoms (table 5). Respiratory symptoms associated with high $Q$ 'p/Q's or PAP/LVP were not associated with changes in the alveolar leucocyte differential (table 5), but they were associated with a lower ELF total protein concentration.

\section{Comparison of CHD with normal controls}

There was no significant difference in BALF alveolar macrophage and lymphocyte differentials between noninfected CHD children and normal controls (table 6). BALF ET-1 was above the detection limit $\left(2.5 \mathrm{pg} \cdot \mathrm{mL}^{-1}\right)$ in $83 \%$ of the $36 \mathrm{CHD}$ children with no LRT infection compared to $23 \%$ of the normal controls $(\mathrm{p}<0.001)$ (fig. 5 and table 6).

Table 5. - Comparison of noninfected CHD children with and without lower respiratory tract symptoms

\begin{tabular}{lccc}
\hline & \multicolumn{3}{c}{ Congenital heart disease group } \\
\cline { 2 - 4 } & $\begin{array}{c}\text { No LRT } \\
\text { symptoms } \\
(\mathrm{n}=32)\end{array}$ & $\begin{array}{c}\text { LRT } \\
\text { symptoms } \\
(\mathrm{n}=8)\end{array}$ & p-value \\
\hline$Q^{\prime} \mathrm{p} / Q^{\prime} \mathrm{s}$ & $1.0(0.8-1.7)$ & $2.8(1.6-3.0)$ & $<0.01$ \\
PAP/LVP & $0.3(0.3-0.3)$ & $0.43(0.3-0.66)$ & $<0.01$ \\
Epithelial lining fluid & & & \\
AM \% & $91.6(85-96)$ & $91.8(81-97)$ & $\mathrm{NS}$ \\
PMN \% & $1.8(0.7-2.9)$ & $1.7(0.5-2.7)$ & $\mathrm{NS}$ \\
LYM \% & $4.0(2.5-8.4)$ & $2.6(1.0-15.7)$ & $\mathrm{NS}$ \\
Total protein & $4.4(3.0-5.7)$ & $2.3(1.6-3.2)$ & $<0.02$ \\
$\quad \mathrm{mg} \cdot \mathrm{mL}^{-1}$ & $332(232-602)$ & 345 & $\mathrm{ND}$ \\
ET-1 pg.mL-1 & $(\mathrm{n}=15)$ & $(\mathrm{n}=2)$ & \\
\hline
\end{tabular}

Values are presented as median, and interquartile range in parenthesis. ND: not determined. For further definitions see legend to table 3 .

Table 6. - Comparison of normal controls with CHD children with no lower airway viral infection

\begin{tabular}{lccc}
\hline & $\begin{array}{c}\text { Normal } \\
\text { controls } \\
(\mathrm{n}=26)\end{array}$ & $\begin{array}{c}\text { Noninfected } \\
\text { CHD group } \\
(\mathrm{n}=36)\end{array}$ & $\mathrm{p}$-value \\
\hline $\begin{array}{l}\text { Age months } \\
\text { Weight kg }\end{array}$ & $19.3(7.3-49.3)$ & $12.0(4.7-17)$ & $\mathrm{NS}$ \\
$\begin{array}{l}\text { Bronchoalveolar } \\
\text { lavage fluid }\end{array}$ & & & \\
Return \% & $55(4.7-17.2)$ & $8.6(5.9-10.4)$ & $<0.01$ \\
Total cells & & $47(36-54)$ & $<0.05$ \\
$\times 10^{3} \cdot \mathrm{mL}^{-1}$ & $175(80-190)$ & $175(115-240)$ & $\mathrm{NS}$ \\
AM \% & $93(90-97)$ & $91(85-96)$ & $\mathrm{NS}$ \\
PMN \% & $0.6(0.3-1.5)$ & $1.6(0.4-2.9)$ & $\mathrm{NS}$ \\
LYM \% & $4.6(2.0-7.4)$ & $4.0(2.3-8.6)$ & $\mathrm{NS}$ \\
ET-1 above assay & $\mathrm{n}=6(23 \%)$ & $\mathrm{n}=30(83 \%)$ & $<0.001$ \\
detection limit ${ }^{\ddagger}$ & & & \\
\hline
\end{tabular}

Values are presented as median, and interquartile range in parenthesis. $\quad$ : in whom endothelin- 1 was analysed; $2.5 \mathrm{pg} \cdot \mathrm{mL}^{-1}$. For definitions see legend to table 3 .

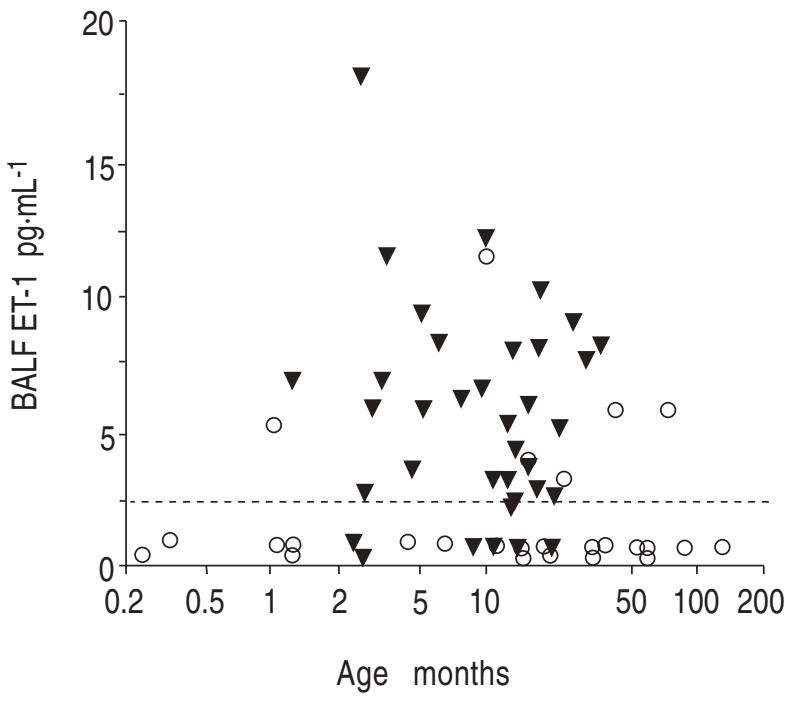

Fig. 5. - Scatterplot of bronchoalveolar fluid (BALF) endothelin-1 (ET-1) in normal controls $(O)$ and noninfected children with congenital heart disease $(\boldsymbol{\nabla})$. Points below the horizontal line ( - - - ) represent ET-1 concentrations below assay detection limit.

\section{Discussion}

In this study, we have demonstrated that LRT viral infection and alterations in pulmonary haemodynamics significantly influence the alveolar milieu of children with CHD. Although NB-BAL and fibreoptic BAL of healthy children result in similar BALF leucocyte differentials [19], the technical aspects of NB-BAL have not yet been fully described. However, in the present study, the high proportion of alveolar macrophages and the relatively low proportion of tracheal ciliated epithelial cells in NB-BALF, suggests that cells and solutes were sampled from the alveoli [20]. Furthermore, dwelltime was always less than $30 \mathrm{~s}$ and any artifactual changes in the urea-estimated ELF volume were minimized [21].

The levels of the ET-1 in the ELF and plasma are of particular interest, as this peptide has been implicated in a wide range of pathological conditions, including asthma [22] and adult respiratory distress syndrome [23]. Reports on changes in plasma ET-1 in children with CHD are contradictory. YoshiBAYASHI et al. [5] found increased plasma ET in CHD children with pulmonary artery-toaortic systolic pressure ratios $>0.5$, and VINCENT et al. [6] reported increased venous ET with high $Q^{\prime} \mathrm{p} / Q^{\prime}$ s, but not with increased pulmonary artery pressure. On the other hand, AdATIA and HawORTH [24] found no difference in plasma ET-1 levels with increased $Q^{\prime} \mathrm{p} / Q^{\prime}$ 's. Our findings are compatible with the latter study, with no effect of either $Q^{\prime} \mathrm{p} / Q^{\prime}$ 's or PAP/LVP on plasma ET-1. However, our CHD cohort did not contain children with the combination of high pulmonary artery pressures and normal/reduced pulmonary blood flows, and the possibility that structural pulmonary hypertension is associated with elevated plasma ET-1 cannot be excluded.

In the CHD group, ELF concentrations of ET-1 were an order of magnitude above those of the plasma, suggesting different rates of ET-1 production and/or removal in the pulmonary vascular and alveolar compartments. 
The source of alveolar ET-1 was not determined in the present study, but alveolar macrophages, fibroblasts and epithelial cells have the capacity to synthesize and release ET-1 locally into the alveolar milieu [7]. ET-1 was undetectable in the BALF in the majority of normal controls, a finding similar to that reported in normal adult BALF [25]. We therefore found indirect evidence for increased pulmonary ET-1 production in CHD, but the presence of multiple stimuli for ET-1 production in CHD, such as cyanosis [26] and abnormal shear forces on the pulmonary endothelium [27], could account for our inability to identify any one stimulatory factor. The role of ET-1 in the pathogenesis of haemodynamic-induced respiratory symptoms is, therefore, unclear.

The observed fall in ELF total protein with increased $Q$ 'p/Q's and/or PAP/LVP in CHD children without LRT infection could result from dilution of protein by an increased volume of alveolar fluid, or diminished protein production within the alveolar space. A fall in plasma protein concentrations with increased $Q$ 'p $/ Q^{\prime}$ s, another possible explanation for a fall in the ELF protein, was not seen in our cohort. Although BAL cannot be used to estimate the absolute alveolar volume, a physiological explanation for the fall in ELF protein concentration is the formation of hydrostatic (low protein) oedema and the dilution of endogenous alveolar proteins. The trend for decreased ELF total cell concentration with increased $Q$ 'p/Q's supports an increase in the volume of alveolar fluid. Indeed, a similar fall both in the ELF total protein concentration and ELF concentration of alveolar cells has been reported during the formation of hydrostatic alveolar oedema in rats [28]. In addition, the association of noninfective LRT symptoms with high $Q$ 'p/Q's, and noninfective LRT symptoms with low concentrations of ELF total protein are compatible with a clinically significant increase in alveolar fluid. In animal studies, increased pulmonary capillary transmural pressure $\left(P_{\mathrm{tm}}\right)$ from left atrial occlusion, results in the formation of proteinrich "permeability" oedema in the alveoli [29]. However, these experiments utilize acute and massive elevations in $P$ tm and are not comparable with the chronic, flowrelated changes in $P$ tm in human CHD.

In the CHD group, viral LRT infection profoundly altered cellularity and protein in the ELF. The viruses detected in the BALF were similar to those causing community-acquired respiratory disease in normal children $[30,31]$. It is possible that the more sensitive detection technique of polymerase chain reaction (PCR) would have identified additional children as potentially infected, but the specificity of PCR when applied to BALF is unknown. The presence of high concentrations of Moraxella catarrhalis and visible intracellular organisms in over half of the virus-infected CHD group was unexpected. Although LRT infection with $M$. catarrhalis and Haemophilus influenzae have been described in association with viral LRT infections [32], the LRT in CHD has not previously been studied. We cannot distinguish the effect of viral infection from viral/bacterial co-infection on the ELF parameters, because of the small numbers of infected children. However, the increase in ELF protein is consistent with the increased permeability of the epithelial-capillary barrier to protein (i.e. "permeability" oedema) reported in the upper respiratory tract of adults with viral colds [33].
Variable increases in alveolar lymphocytes and neutrophils occur during experimental viral infections [9, $10]$. Similarly, we found that LRT viral infection was associated with either an ELF neutrophilia or an ELF lymphocytosis. Since, by definition, the alveolar macrophage differential falls with both increased neutrophil and lymphocyte differential counts, the macrophage differential was the most sensitive marker of infection-induced inflammation. Although our cut-off point was defined retrospectively, an alveolar macrophage differential of $\geq 80 \%$ would exclude all the infected CHD children (fig. 1). Since respiratory symptoms due to increased pulmonary blood flow did not affect the alveolar macrophage differential, BAL performed during preoperative catheterization may have a future role. If the macrophage differential is normal at catheterization, the surgeon can be rapidly reassured that respiratory infection is unlikely, even if the child exhibits tachypnoea and wheezing. If the macrophage differential is depressed, surgery could be delayed until viral cultures are available.

In conclusion, there are at least two factors in congenital heart disease that influence the alveolar milieu, pulmonary haemodynamics and infection. We have demonstrated a decrease in protein concentration in the epithelial lining fluid associated with increased pulmonary blood flow, and speculate that this reflects the formation of proteindepleted hydrostatic oedema in the alveoli. We could not define which factor in congenital heart disease predisposes to the accumulation of endothelin- 1 in the epithelial lining fluid and the relationship between alveolar endothelin-1 and lower respiratory tract symptoms remains unclear. Nonbronchoscopic bronchoalveolar lavage of children undergoing cardiac catheterization not only provides insights into cardiopulmonary interactions, but also appears to be a promising method for rapidly assessing the infection status of the lower airway.

Acknowledgements: The authors are grateful to the Department of Microbiology and Infectious Diseases, and The Department of Virology, Royal Children's Hospital, Melbourne for their technical support.

\section{References}

1. Griffin AJ, Ferrara JD, Lax JO, Cassels DE. Pulmonary compliance: an index of cardiovascular status in infancy. Am J Dis Child 1972; 123: 89-95.

2. Hordof AJ, Mellins RB, Gersony WM, Steeg CN. Reversibility of chronic obstructive lung disease in infants following repair of ventricular septal defect. J Pediatr 1977; 90: 187-191.

3. The BAL Cooperative Group Steering Committee. Bronchoalveolar lavage constituents in healthy individuals, idiopathic pulmonary fibrosis, and selected comparison groups. Am Rev Respir Dis 1990; 141: S169-S202.

4. Grigg JM, Barber A, Silverman M. Increased levels of bronchoalveolar lavage fluid interleukin-6 in preterm ventilated infants after prolonged rupture of membranes. Am Rev Respir Dis 1992; 145: 782-786.

5. Yoshibayashi M, Nishioka K, Nakao K, et al. Plasma endothelin concentrations in patients with pulmonary hypertension associated with congenital heart defects. Circulation 1991; 84: 2280-2285.

6. Vincent JA, Ross RD, Kassab J, Hsu JM, Pinsky WW. Relation of elevated plasma endothelin in congenital heart 
disease to increased pulmonary blood flow. Am J Cardiol 1993; 71: 1204-1207.

7. Barnes PJ. Endothelins and pulmonary diseases. J Appl Physiol 1994; 77: 1051-1059.

8. Fraenkel DJ, Bardin PG, Sanderson G, Lampe F, Johnston SL, Holgate ST. Lower airways inflammation during rhinovirus colds in normal and in asthmatic subjects. Am J Respir Crit Care Med 1995; 151: 879-886.

9. Openshaw PJM. Flow cytometric analysis of pulmonary lymphocytes from mice infected with respiratory syncytial virus. Clin Exp Immunol 1989; 75: 324-328.

10. Azoulay-Dupuis E, Lambre CR, Soler P, Moreau J, Thibon M. Lung alterations in guinea-pigs infected with influenza virus. J Comp Pathol 1984; 94: 273-283.

11. Rusconi F, Castagneto M, Gagliardi L, et al. Reference values for respiratory rate in the first 3 years of life. Pediatrics 1994; 94: 350-355.

12. Koumbourlis AC, Kurland G. Nonbronchoscopic bronchoalveolar lavage in mechanically ventilated infants: technique, efficacy, and applications. Pediatr Pulmonol 1993; 15: 257-262.

13. Riedler J, Grigg J, Stone C, Tauro G, Robertson CF. Bronchoalveolar lavage cellularity in healthy children. Am Respir Crit Care Med 1995; 152: 163-168.

14. Ganong WF. In: Review of Medical Physiology. Los Altos, CA, Lange Medical, 1983; pp. 463-464.

15. Baselski VS, El-Torky M, Coalson JJ, Griffin JP. The standardization of criteria for processing and interpreting laboratory specimens in patients with suspected ventilator- associated pneumonia. Chest 1992; 102 (Suppl.): 571S-579S.

16. McDowell TL. Benzethonium chloride method for proteins adapted to centrifugal analysis. Clin Chem 1985; 6: 864-866.

17. Rennard SI, Basset G, Lecossier D, et al. Estimation of volume of epithelial lining fluid recovered by lavage using urea as a marker of dilution. J Appl Physiol 1986; 60: 532-538.

18. Merchant RK, Schwartz DA, Helmers RA, Dayton CS, Hunninghake GW. Bronchoalveolar lavage cellularity: the distribution in normal volunteers. Am Rev Respir Dis 1992; 146: 448-455.

19. Grigg J, Riedler J, Robertson C. Bronchoalveolar lavage of children without pulmonary pathology using a wedged suction catheter. Am J Respir Crit Care Med 1994; 149: A371.

20. Rennard SI, Ghafouri MD, Thompson AB, et al. Fractional processing of sequential bronchoalveolar lavage to separate bronchial and alveolar samples. Am Rev Respir Dis 1990; 141: 208-217.
21. Marcy TW, Merrill WW, Rankin JA, Reynolds HY. Limitations of using urea to quantify epithelial lining fluid recovered by bronchoalveolar lavage. Am Rev Respir Dis 1987; 135: 1276-1280.

22. Vittori E, Marini M, Fasoli A, Franchis RD, Mattoli S. Increased expression of endothelin in bronchial epithelial cells of asthmatic patients and effect of corticosteroids. Am Rev Respir Dis 1992; 146: 1320-1325.

23. Langleben D, Demarchie M, Laporta D, Spanier AH, Schlesinger RD, Stewart DJ. Endothelin-1 in acute lung injury and the adult respiratory distress syndrome. Am Rev Respir Dis 1993; 148: 1646-1650.

24. Adatia I, Haworth SG. Circulating endothelin in children with congenital heart disease. Br Heart J 1993; 69: 233-236.

25. Sofia M, Mormile M, Faraone S, et al. Increased endothelin-like immunoreactive material on bronchoalveolar lavage fluid from patients with bronchial asthma and patients with interstitial lung disease. Respiration 1993; 60: 89-95.

26. Li H, Chen S-J, Chen Y-F, et al. Enhanced endothelin1 and endothelin receptor gene expression in chronic hypoxia. J Appl Physiol 1994; 77: 1451-1459.

27. Yoshizumi M, Kurihara H, Sugiyama T, et al. Hemodynamic shear stress stimulates endothelin production by cultured endothelial cells. Biochem Biophys Res Commun 1989; 161: 859-864.

28. Dreyfuss D, Soler P, Saumon G. Spontaneous resolution of pulmonary edema caused by short periods of cyclic overinflation. J Appl Physiol 1992; 72: 20812089.

29. Tsukimoto K, Yoshimura N, Ichioka M, et al. Protein, cell, and $\mathrm{LTB}_{4}$ concentrations of lung edema fluid produced by high capillary pressures in the rabbit. $J$ Appl Physiol 1994; 76: 321-327.

30. Zandotti CM, Delamballerie XN, Vignoli C, Garnier JM. Simultaneous pulmonary infection with respiratory syncytial virus and human cytomegalovirus. Arch Dis Child 1994; 70: 452.

31. Abramson JS, Wheeler JG. Virus-induced neutrophil dysfunction: role in the pathogenesis of bacterial infections. Pediatr Infect Dis J 1994; 13: 643-652.

32. Faden H, Harabuchi Y, Hong JJ, and Tonawanda/ Williamsville Pediatrics. Epidemiology of Moraxella catarrhalis in children during the first 2 years of life: relationship to otitis media. J Infect Dis 1994; 169: 1312-1317.

33. Naclerio RM, Proud D, Lichtenstein LM, et al. Kinins are generated during experimental rhinovirus colds. $J$ Infect Dis 1988; 157: 133-142. 